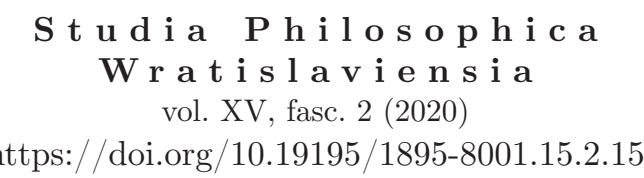

MIROSŁAW ŻAROWSKI

ORCID: 0000-0002-5644-2612

Uniwersytet Wrocławski

\title{
Pochwała człowieka ludzkiego w Kronice Kadłubka. U samych początków myśli polskiej, u końca czasu
}

\author{
Apology of the Affable Man in Kadłubek's Chronicle: \\ At the Beginning of Polish Thought, at the End of Time
}

\begin{abstract}
Starting with the words that finish, or interrupt Master Wincenty's Polish Chronicle, I interpret its historiographic content as characteristic of 12th century humanism, expression of love, of wisdom. The infallible condition of ethical arete may be found to be formulated in the last words of the Chronicle concerning humanity (affabilitas, humanitas) which consists in tolerant indulgence of others' vices and modesty about one's virtues.
\end{abstract}

Keywords: Wincenty Kadłubek, history of Polish philosophy, philosophy of the 12 th century, history of historiography, ancient and medieval rhetoric

Icareum per me cur interetur iter? „Po cóż Ikara lot ja naśladować bym miał?”

(III.20.145)

\section{Finit Cronica}

Kronika polska Mistrza Wincentego zwanego Kadłubkiem (†1223) kończy się czy też, jak sądzi większość badaczy, urywa się na zdaniu: 
Qui tam accessibilem, tam favorabilem, tam benignum, tam dulcem et sueuem habuit contra omnes uoluntatem affirentio. Ideoque ne aliorum crederetur defectus contemnere, immo ne de propriis uideretur arrogantior urtutibus, sese offerebat cunctis affabilitate prestabilem.

Onże okazywał wszystkim tak przystępną, tak ujmującą, tak łaskawą, tak słodką i miłą, ufną życzliwość, że - aby nie mniemano, iż ma w pogardzie błędy drugich — a jeszcze bardziej, iżby się nie zdawało, że jest zadufany we własnych przymiotach, wszystkim okazywał się nadzwyczaj ludzkim. $(\mathrm{IV} .26 .273)^{1}$

Zważywszy na niedomknięcie narracyjnego wątku, brak oczekiwanej konkluzji lub listu dedykacyjnego, pytała czcigodna tłumaczka i znawczyni dzieła Brygida Kürbis: „Dlaczego przestał pisać? Nie śmiemy domyślać się za wiele, mianowicie, że zniszczono mu kontynuację i ewentualne zakończenie"2.

Nie zamierzamy i my rozstrzygać o okolicznościach zaprzestania czy też zakończenia przedsięwzięcia pisarskiego w wypadku tak wytrawnego i obdarzonego tej miary zmysłem kompozycyjnym stylisty, jakim był Wincenty — pisarz, o czym dobitnie poucza prolog kroniki, wzdragający się równie mocno przed wypowiedzeniem pierwszego co posiadaniem ostatniego słowa. Obdarzony słuchem muzycznym, wrażliwy na rytm i warstwę brzmieniową wyrazów pisze i myśli całymi akapitami, a zarazem w granicach ornatus difficilis — „trudnej ozdobności”, okazując gramatyczną, retoryczną i dialektyczną biegłość, panuje już na poziomie składni nad najmniejszymi jednostkami stylistycznymi, iż nie tylko każde zdanie, lecz każde słowo może być, tak jakby miało być, ostatnim. Nie domyślamy się intrygi mogącej pisanie lub czytanie tekstu pozbawić kontynuacji, zakończenia, końcowego przesłania, morału, jakkolwiek walka polityczna o pryncypat w epoce rozbicia dzielnicowego sprzyjała temu i mogła być również przyczyną, zapewne nie jedyną ani najważniejszą, złożenia przez Wincentego sakry biskupiej. Nie wiemy i być może nigdy się nie dowiemy, czy formuła będąca dopiskiem obcej ręki w kolofonie rękopisu tak zwanego Eugeniuszowskiego, najbliższego oryginałowi: finit Cronica rzeczywiście (nie) odpowiada autorskiej intencji.

Przez wzgląd na coraz liczniejsze, w miarę zbliżania się do siebie czasu opowiadania i czasu opowiadanego, powody rezygnacji z pisania lub odmowy czytania - coraz liczniejsze, a zarazem trudniejsze do weryfikacji, poprzestańmy na uwadze, że przytoczone słowa, na których albo w których urywa się bądź też kończy zarówno tekstura, jak i lektura kroniki, chociaż stanowią pochwałę, zapewne hiperboliczną, kolejnego Piasta zasiadającego w roku 1205 na tronie książęcym w Krakowie, odnosząc się do chwalącego bodaj bardziej niż do chwalonego, trudno zrazu dopatrzyć się w nich zwieńczenia lub choćby tylko fragmentu typowego tekstu historiografii. A jest to fragment, ostatni z brzegu, dla Kadłubkowego stylu

${ }^{1}$ Fragmenty Kroniki polskiej przytaczam za: Mistrz Wincenty (tzw. Kadłubek), Kronika Polska, tłum. B. Kürbis, Wrocław-Warszawa-Kraków 1992. Paginację zaznaczam w tekście głównym, uwzględniając kolejno numer księgi, rozdziału i stronicy tego właśnie wydania. Słowa oryginału łacińskiego czerpię z edycji: Magistri Vincentii dicta Kadtubek Chronica Polonorum, M. Plezia (red.), Kraków 1994.

${ }^{2}$ B. Kürbis, Wstęp, [w:] Mistrz Wincenty (tzw. Kadłubek), Kronika Polska, s. XXXV. Mowa o objęciu na krótko pryncypatu przez ks. Władysława Laskonogiego. „Na tym Kronika się urywa. Które wydarzenie miało zamknąć dzieło — nie wiemy" — ibidem, s. LX. 
uprawiania historii i dla stylu jego myślenia znamienny, gdy w kwiecistym, kunsztownym i syntaktycznie wyrafinowanym języku wypowiada moralny frazes o godności prostolinijnego, cnotliwego, ludzkiego człowieka, który w swym życzliwym usposobieniu i zaufaniu (affidentia) wobec innych ludzi jest właśnie w chwili swego wywyższenia accessibilis — przystępny, favorabilis — ujmujacy i przychylny, benignus - łaskawy i dobrotliwy, dulcis et suevis — słodki i przyjemny. Frazes ten pozostaje oczywisty dla wszystkich dopóty tylko, dopóki wybrzmiewa, wraz z zamilknięciem mówcy lub krawędzią pergaminowej karty stając się na powrót tym, co najbardziej zagadkowe, a kulminujące w niewiadomej ponawianego przez istotę myślącą, śmiertelną pytania o właściwy jej sposób życia. Cóż bowiem znaczy dla człowieka „okazywanie się ludzkim”, a cóż „nadzwyczaj ludzkim” po to, aby jego życzliwość i ufność wobec innych ludzi nie była źle zrozumiana jako mianowicie wyraz lekceważenia cudzych wad i przeceniania własnych zalet? I na jakim uniwersyteckim fakultecie, wówczas - $\mathrm{u}$ zarania universitas i dziś - $\mathrm{u}$ jej schyłku, poszukiwać należy odpowiedzi na tak szczegółowe, a jednocześnie nazbyt ogólne pytania?

Z potrzebą, możliwością, koniecznością filozofowania spotyka się tymczasem, na miarę humanizmu i renesansu XII stulecia, człowiek, jak słyszymy, „nadzwyczaj ludzki", wystarczająco ludzki, aby żyjąc z innymi i pośród innych, żeglować ze zmiennym, a raczej niezmiennym szczęściem, jeśli szczęście i cnota miałyby być tym samym, pomiędzy Scyllą pogardy lub obojętności wobec cudzych przywar a Charybdą zarozumiałości, arogancji i pychy wobec własnych przymiotów, i nazbyt skwapliwie nie potępiać tych, których uważa za lepszych od siebie, a uznawanych za gorszych od siebie nie chwalić. W byciu nim terminuje zarówno sam autor ubiegający się o dziejopisarską wiarygodność zgodnie ze strategią captatio benevolentiae, jak i postaci, autentyczne lub zmyślone, świata w kronice przedstawionego: pobożny, wykształcony, wyrobiony artystycznie, przytomny moralnie, cierpliwie i wytrwale dążący do dobrego, cnotliwego życia, przyjazny wobec innych ludzi i siebie, miły w obcowaniu, hołdujący prostocie, szlachetny, szczerze przejmujący się losem swojej ziemskiej ojczyzny. Człowiek wyróżniający się ludzkością i celujący w niej (affabilitate praestabilis), którym także czytelnikowi Kroniki polskiej jako dzieła utrzymanego w ,biograficzno-epidejktyczno-parenetycznej poetyce"3 pod wpływem lektury łatwiej się stać — po drodze jeśli nie do świętości, to przynajmniej do uczciwości.

Czy słowa tak czy inaczej zamykające kronikę otwierają przestrzeń dla filozoficznego myślenia? Czy myśl odnajduje się w słowach retorycznie wyszukanych, czy też raczej gubi się w nich? Czy zyskuje na ścisłości i znaczeniu poddana rygorowi diakrytycznych znaków i prozodycznych różnic, gdy średniowieczny mówca odżegnuje się w słowach od tego, co właśnie w nich i nimi czyni — jak w pytaniu po dwakroć retorycznym o powody, dla których miałby naśladować lot Ikara? Jak zaczyna się to, co się tak właśnie kończy, i gdzie przebiegają wewnętrzne linie podziału, aby tekst mógł urywać się tam, gdzie się Kadłubkowy urywa — zważywszy

${ }^{3}$ J. Domański, Sprawiedliwość $i$ miłosierdzie w systemie cnót politycznych Wincentego Kadłubka, „Teologia Polityczna. Rocznik Filozoficzny” 1-2 (2003-2004), s. 159. 
na istotową niekonkluzywność historii, a aktu stawania się niezupełność, jeśli nie gdziekolwiek bądź, to na pochwale widzialności i objawiania się w niej wszystkim ludziom ludzkiego człowieka, który zdolny jest nadać swemu zaufaniu wobec innych szlachetny pozór etycznej niezawodności?

Przedkładając odautorskie referencje dyktowane eksordialną topiką skruchy i afektowanej skromności, zawartą pomiędzy dwiema trwałymi dyspozycjami zdobiącymi średniowiecznego pisarza: humilitas i humanitas - pokorą i ludzkością, przedstawia siebie Mistrz Wincenty jako skrajnie w talenty i apanaże ubogiego poetę, daremnie u końca czasów, gdy napisano już wszystko, poszukującego powodów pisania (causa scribendi) innych niźli te, które byłyby już jego motywami (ratio legendi). Wobec powierzonej sobie misji opowiedzenia dziejów ojczystych ma się za "karzełka” dźwigającego na swych wątłych barkach „brzemię Atlasa” (humeris Pygmei onus imposuit Athlanteum), za nieudolnego artystę, który już wielokrotnie przeżywał zasłużoną gorycz twórczych niepowodzeń, skrybę dzierżącego niewprawnymi palcami jak trzcina „łamliwe pióro” (calamus fragilis), które winno przecież sprostać godnemu powadze poruszonych spraw stylowi wielkiemu i ozdobnemu, a przy tym nie pominąć żadnego z nieistotnych na pozór szczegółów, w jakie historia obfituje, skoro ,nie jest rzeczą błahą w ludzkich sprawach lekceważyć błahostki" (II.4.44).

Sam początek kroniki jest nie mniej arbitralny od jej końca, chociaż nikt nigdy prologowi nie odmawiał autorskiej inwencji ani nie zaprzeczał temu, że w stosunku do ostatnich słów dzieła prolog, pisany być może po jego zakończeniu, jest epilogiem. Pierwsze, inicjalne zdanie, które z powodu braku oryginalnego tytułu uchodziło w średniowieczu za znak rozpoznawczy dzieła, natychmiast osiąga postulowaną jedność treści i formy, a wywołuje wrażenie drugiej nad pierwszą przewagi, gdy w rozbudowanej, kunsztownej konstrukcji - trójdzielnej i trzykrotnie powracającej, a zaznaczanej spółgłoską lub literą "„t” (tres, tribus, theatrales), traktuje o przyczynach odmowy, niechęci, nienawiści:

Trzech [ich] było, którzy z trzech powodów nienawidzili uroczystości teatralnych: pierwszego imię Kodrus, drugiego Alkibiades, trzeciego Diogenes. Kodrus, ponieważ był ubogi i łachmanami okryty, drugi, ponieważ był niezwykle urodziwy, trzeci, ponieważ i grzecznością obyczajów się odznaczał i w głębokie myśli obfitował. Pierwszy, aby i tak już budzącego śmiech ubóstwa nie wystawiać na ogólne pośmiewisko; drugi, aby nie narażać się na niebezpieczeństwo uroków; trzeci, aby nieskalanego majestatu mądrości nie wydawać na błazeńską poniewierkę. (Prol.1.3)

Przystępując do pracy i antycypując jej tyleż wzniosły, co nieuchronnie żałosny koniec w ,arcybogatym, żywym i swobodnym języku, łacinie wręcz klasycznej, o umiejętnie rozłożonych akcentach i kadencjach rytmicznych"s, zna Mistrz Wincenty dostateczne powody, dla których człowiek mądry „odznaczający się grzecz-

\footnotetext{
4 Jest zagadnieniem otwartym, czy kronika Wincentego zwraca się ku słuchaczom, czy czytelnikom, i co okazuje się ostatecznie jej żywiołem: oralność czy skrypturalność. W odróżnieniu od większości badaczy podkreślających w tym kontekście raczej synkretyzm Kadłubka Witold Wojtowicz pisze: „»Wykonanie« ma stać się partycypacją pisemną, nie ustną tekstu — autora, ale nie aktora" — idem, Niektóre aspekty retoryczne Prologu Kroniki Mistrza Wincentego, [w:] Teatr wymowy. Formy i przemiany retoryki użytkowej, J. Sztachelska, J. Maciejewski, E. Dąbrowska (red.), Białystok 2004, s. 51.

${ }^{5}$ B. Kürbis, Wstęp, s. LXXXI.
} 
nością, zasobny jak Diogenes w „głębokie myśli” i „natchnione zdanie” (diuina sententia), jak Alcybiades urodziwy lub choćby tylko ubogi jak Kodrus powinien trzymać się z daleka od theatrales solempnitates — „dorocznych przedstawień teatralnych", aby mianowicie swojej kondycji znaczonej cantissima prudantiae maiestas — „nieskalanym majestatem mądrości”, szlachetnym pięknem lub radosnym ubóstwem ,nie narażać”, „nie wystawiać”, „nie wydawać” na publiczny, płynący ze zbytniej poufałości i kaprysów rozwiązłego tłumu incest ${ }^{6}$. Nie żądzą zysku powodowany lub pragnieniem sławy ani godną pożałowania „namiętnością pisania”, ową chorobą polegającą na właściwym dla grafomanów „złym charakterze” pisma i prowadzenia się, lecz wyłącznie nakłoniony sprawiedliwym, stanowczym, urzędowym nakazem władcy oraz wewnętrznym, pomiędzy groźbami pychy i zaniechania rachunkiem artystycznego sumienia waży się u kresu historii inicjować opowieść o początkach Rzeczypospolitej, które za jego sprawą, w języku w równej mierze konstatującym co performatywnym, mają się dopiero wydarzyć. Józef Ignacy Kraszewski pisał: „Jest to więcej niż kronika, jest to historya opowiedziana w sposób dowodzący głębokiej przenikliwości, wyższego spraw ludzkich pojęcia"8.

Niezależnie od tego, jak dalece owo oryginalne znamię stylu dowodzi filozoficznego zaangażowania autora i do jakiego stopnia oczekiwanie początku u końca czasu nie może nie skutkować „ponownym rozbiciem się na tych samych ławicach” (Prol.3.5) lub podniebną katastrofą Ikara, „prolog do Kroniki — pisze Brygida Kürbis - zaczynający się od słów Tres tribus ex causis zapowiada coś więcej niż relację historyczną"9, a nawet, jak się wydaje, zapowiada raczej wszystko inne aniżeli ją. Juliusz Domański zauważa z kolei: „to zaskakująca, zgoła nieoczekiwana na początku kroniki, ekspozycja trzech przykładów niechęci do bynajmniej nie od razu zrozumiałych theatrales sollemnitates" ${ }^{10}$. O czym, zapytajmy, będzie to, co na ów sposób, jednocześnie zdumiewający i dziwaczny, perfekcyjny i manieryczny, inicjuje własny początek, i na czym, odstępując od swego przedmiotu, powinno się ono zakończyć lub urwać wedle naturalnej, wynikającej z dyspozycji formy i materiału linii podziału?

Rozpoczynając od „opatrzonych aż potrójną eksplikacją"11 przyczyn unikania uczestnictwa $\mathrm{w}$ widowiskach teatralnych, nie gdzie indziej jednak jak właśnie na ustanawianej w słowach i dla słów scenie, w feerii antytez i anafor staje zdjęty lękiem autor, aby w aurze literackiego debiutu i erudycyjnego znużenia projektować przytomność przyszłych czytelników i słuchaczy. Trzej Grecy pojawiający się, niejako wbrew sobie, na początku wstępu czy tė̇ we wstępie do początku mowy, która jako insinuatio polega, zdaniem Cycerona, na „krążeniu wokół” (circumi-

${ }^{6} \mathrm{O}$ incestus, przed którym uchronić pragnie Kadłubkowy Diogenes swoją mądrość, w znaczeniu „kazirodztwa”, „kalania” i „czynienia nieczystym” zob. J. Domański, Prolog „Kroniki polskiej” Mistrza Wincentego zwanego Kadtubkiem. Próba enarracji, „Przegląd Tomistyczny” 12 (2006), s. 25.

7 Źródłem grecyzmu scribendi cathetes/cacoethes, mającym być może za pośrednika Jana z Salisbury, był Juwenalis (Satyry, VII 52). Od greckiego słowa xaxoń $\theta$ n — niemoralny, nieobyczajny.

8 J.I. Kraszewski, Odczyty o cywilizacyi w Polsce, Warszawa 1861, s. 106.

${ }^{9}$ B. Kürbis, Wstęp, s. LX.

10 J. Domański, Prolog „Kroniki polskiej”..., s. 14.

11 Ibidem, s. 17. 
tio) i „udawaniu” (dissimulatio) po to, by nie zdradzić przedwcześnie właściwego tematu dzieła ${ }^{12}$; reprezentują zapewne trzy jego warstwy podstawowe: Diogenes - mądrościową treść, Alkibiades - estetyczną formę wyrazu, Kodrus - cechy genologiczne wypowiedzi zdeterminowane dojmującym, a historii właściwym niedostatkiem źródeł. Ich stawiennictwo każe jednak wbrew zasadzie omne trinum perfectum, a w analogii do platońskiego Timajosa pytać o przyczyny nieobecności czwartego $^{13}$.

Niemądry i nieurodziwy, jeśli już, to poczuwający się do solidarności losu z Kodrusem, a nawet uboższy od niego, ponieważ „niemający nawet łachmana, którym mógłby okryć swój wstyd" (Prol.2.4), nieledwie niezręczny czeladnik heksametru daktylicznego, nominowany na narratora bezimienny sługa wcześniej ,noszaccy kałamarz z piórem" (quidam uernaculus atramentarium gestans) (IV.1.175), niepozorny, ,jedyny i poszczególny rachmistrz Rzeczypospolitej” (unicus ac singularis rei publicae rationalis), prowadzący rejestr przychodów i wydatków (IV.1.175), a zarazem niezborny szafarz słów, któremu ,mądrość nie użyczyła ani kropelki łaski” (Prol.2.4) przytacza w swojej, jak sam się wyraża, pagella — „książeczce” jałowej i suchej, gwoli rzetelności pisarskiej i ku pożytkowi czytelników, całą plejadę antycznych i średniowiecznych myślicieli. W ich liczbie napotykamy Platona w Chalcydiuszowym przekładzie dialogu Timajos, Arystotelesa, Senekę, Cycerona, Boecjusza, Kwintyliana, Makrobiusza, Marcjana Capellę. Miejscami Wincenty przywodzi na myśl czasowo bliższych sobie: św. Bernarda z Clairvaux, Teodoryka z Chartres, Wilhelma z Conches, Bernarda Silvestris, Alana z Lille, Jana z Salisbury, przemierzając drogi tyleż chartryjskiej, co cysterskiej duchowości. Pojawiają się wielokrotnie w anegdotycznym i doksograficznym trybie Filozof i Mędrzec mistrzowie ascezy i radosnego ubóstwa obleczeni w synkretyczne, chrześcijańsko-stoickie szaty, a nawet sofista-Sokrates pod postacią legendarnego Kraka ${ }^{14}$, odkrywający przed Polakami definicję sprawiedliwości, która formułowana pomiędzy platońskim Państwem a Timajosem „sprzyja najbardziej temu, kto może najmniej” (I.5.13). Imiennie zaś, niby aktorów wywołanych na scenę dla wypowiedzenia lub choćby poświadczenia swych mądrościowych kwestii, słyszymy: prawodawcę ateńskiego Solona, Diogenesa - cynika z Synopy lub stoika z Babilonu ${ }^{15}$, Damona

${ }^{12}$ M.T. Cyceron, De inventione, I, 15, 20; E. Skibiński, Gramatyka i retoryka w „Chronika Polonorum” mistrza Wincentego zwanego Kadłubkiem. Forma językowa na ustugach myśli [praca doktorska napisana pod kierunkiem B. Kürbis, Poznań 1993], s. 147.

${ }^{13}$ Istnieje wyraźna paralela, godna wnikliwszej analizy, między początkiem dialogu ramowego w Platońskim Timajosie a prologiem Kroniki polskiej.

${ }^{14}$ Sam legendarny Krak — sententioso agminae beatus (I.5.12) zostaje określony słowami, którymi Sokrates charakteryzuje sofistów (Timajos 19e). Timaeus a Calcidio translatus commentarioque instructus, J.H. Waszink (red.), London-Leiden 1975, s. 11, 4-9. Definicja sprawiedliwości zaś pochodzi z listu wstępnego Orosio suo Calcidius, w którym tłumacz Timajosa powraca myślami do dyskusji Sokratesa z Trazymachem w dialogu Państwo. Timaeus a Calcidio translatus, s. 5, 3. Zob. J. Mańkowski, Krak, uczeń Sokratesa (glosa do Kadtubka Chronica Polonorum I 5,3), [w:] Inspiracje platońskie literatury staropolskiej, A. Nowicka-Jeżowa, P. Stępień (red.), Warszawa 2000, s. 147-150.

15 Zazwyczaj Diogenes występujący w prologu Kroniki identyfikowany jest z Diogenesem z Synopy. Należy jednak zaznaczyć, że Diogenes z Babilonu, uczeń Chryzypa, jest wielokrotnie wspominany w dostępnych Wincentemu pismach Cycerona i określany tam jako magnus et gravis stoicus. M.T. Cyceron, 
i Fintiasza, uczniów Pitagorasa, a nauczycieli szlachetnej sztuki przyjaźni, spośród uczniów Stagiryty zaś Eudemosa z Rodos, Teofrasta i Kallistenesa - autorytatywnych, obok malarza Deuksisa, znawców natury ludzkiej.

Mimo, czy może właśnie dlatego, że jedna z pierwszych w naszym kraju miarodajnych prób filozofowania, rozpoczynająca się od świadectwa trzech Greków o sokratycznych, może nawet sokratejskich rysach, którzy woląc raczej „uchylać się od oglądania innych niż innym z siebie wzgardliwe czynić widowisko" (Prol.1.3), mają w nienawiści blichtr publicznych wystąpień, a kończąca się pochwałą księcia, wydającego się w oczach wszystkich (contra omnes) człowiekiem nadzwyczaj ludzkim, aby swą życzliwość i wielkoduszność uchronić przed zarzutem lekkomyślności lub pogardy, posiada, zwłaszcza w warstwie erudycyjnej, imponujący już na pierwszy rzut oka, monumentalny wręcz charakter, przejawiający się w mnogości nawiązań i aluzji filozoficznych, które wszelako pełnią funkcję, do jakiej historycy filozofii nie nawykli — stylistycznych ornamentów i narracyjnych incydentów. Długo trwało oswajanie się z myślą, że w zabytku średniowiecznego dziejopisarstwa, niespełniającym nawet wymogów pragmatycznej, cóż dopiero krytycznej i naukowej historiografii, obecna jest filozofia wyrazista i konsekwentna na tyle, aby zasługiwała na potraktowanie jej z należytą uwagą. Będąca czymś więcej niż tylko ostentacyjnym, podporządkowanym funkcji estetycznej i dydaktycznej sztafażem, uwięzionym nadto nie tylko w moralnych frazesach o wybujałej frazeologii, ale i w bezliku cytatów czerpanych z innych źródeł: Biblii i pism Ojców Kościoła, prozy i poezji łacińskiej, a także prawniczych kodeksów.

Wielce znamienna jest w owej erudycyjnej, intertekstualnej, a jednak opartej na niedostatku źródeł mozaice cytatów i kryptocytatów „obecność Arystotelesa w miejscach, w których nikt się nie spodziewał go zastać"16 "gdy najpoważniejszym pouczeniem dającym do myślenia dwunastowiecznemu humaniście i bohaterom jego sagi jest wyprowadzana z Topik, ,zgoła wyjątkowa, jak na widnokręgi teologiczno-scholastyczne, definicja człowieka"17: homo est animal mansuetum natura — „człowiek jest z natury zwierzęciem łagodnym”. Określenie to będące w tekście Stagiryty, z wolna przyswajanym dopiero w ramach logica nova, jedynie przykładem w kontekście rozważań dotyczaccych własności atrybutywnych i akcydentalnych, urasta w Kronice polskiej do rangi antropologicznej zasady i kluczowego argumentu, którym posługuje się w swojej mowie obrończej oskarżany o zdradę

O powinnościach, III, 12, 51, [w:] idem, Pisma filozoficzne, tłum. W. Kornatowski, t. 2, Warszawa 1960, s. 496-497. Władysław Tatarkiewicz uważa go za prekursora Cycerona, św. Augustyna, Izydora z Sewilli i Hugona od św. Wiktora, gdy idzie o sformułowanie zasady decorum i aptum - idem, Dzieje sześciu pojęć, Warszawa 1982, s. 187. Wiemy, że poszukiwał gatunku muzyki, która byłaby najbardziej odpowiednia dla filozoficznej biesiady. Ceniono jego zdanie, zapewne „natchnione” (divina sententia), o bogu i Wielkim Roku.

${ }^{16}$ Z. Kałuża, Kadłubka historia mówiona i historia pisana („Kronika” I 1-2, I 9 i II 1-2), „Przegląd Tomistyczny" 12 (2006), s. 62.

17 Arystoteles, Topiki 128b. Ową „definicję" łączy Balzer z „poglądem, żywo przypominającym stanowisko Pliniusza, który szedł tu zresztą za Arystotelesem" — idem, Studyum o Kadłubku, t. 1, [w:] Pisma pośmiertne Oswalda Balzera, t. 1, Lwów 1934, s. 388. 
ojczyzny Zbigniew (II.28.109) ${ }^{18}$. Dowiadujemy się więc w trakcie rozprawy sądowej

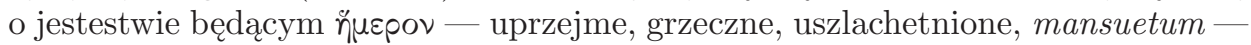
ujarzmione, oswojone, obłaskawione, udomowione, w swych największych nawet nieprawościach nigdy dość dzikie i przewrotne, aby świadomie zmierzać do zła jako zła, a zarazem nazbyt potulne i uległe, aby móc sprzeciwić się zasadom wpojonym mu w trakcie wychowania. Żaden tedy człowiek dopóty, dopóki człowiekiem pozostaje, nie jest zdolny sam w sobie do tak wielkiej niegodziwości, o jaką jest posądzany, „nie ma bowiem powodu, który mógłby nas popchnąć przeciw sobie samym” (II.28.108), zwłaszcza gdy sam do sentencji o łagodności ludzkiej natury odwołuje się, urzeczywistniając niezbywalne prawo oskarżonego do obrony. Odsyłając adwersarzy do swojej, jako człowieka właśnie, przyrodzonej mansuetudo, którą legitymizuje rozsądek, powiada Zbigniew: „Jakimże więc sposobem ktoś rozsądny mógłby wzdychać do zagłady tego, co [sam] pragnąłby posiąść na zawsze? Wszystko bowiem, co choćby niewielką nęci człowieka przyjemnością, w najczulszych tuli on objęciach" (II.28.109). Oto ostatnia rubież obrony godności człowieka i poręczenie jego uprawnień do samego siebie, nawet jeśli wyimaginowana rozprawa sądowa kończy się wyrokiem skazującym na wieczne wygnanie, a ludzka łagodność okazuje się jedynie nieudolną imitacją Tego, kto stawszy się człowiekiem, jest najbardziej stosownym humilitatis exemplum — „przykładem pokory” i mansuetudinis forma - „pierwowzorem łagodności"19.

Cel dawnej historiografii, wyrażając w słowach: „dopuścić potomnych do udziału w cnotach pradziadów" (Prol.4.5), wypowiada Wincenty moralny truizm i staroświecki dydaktyczny eufemizm, łatwe do przeoczenia. Wszak o tym, że „wszelkie dowody dzielności, wszelkie oznaki zacności odbijają się w przykładach przodków jakby w jakimś zwierciadle" (Prol.4.5), wiedzą wszyscy, nie tylko książę Kazimierz Sprawiedliwy - zleceniodawca kroniki, choć jedynie niektórzy mają odwagę zgłębiać hermeneutykę i optykę tej zachłannej więzi, powierzając swoje rozumienie i patrzenie serii lustrzanych odbić, a odtwarzając w myślach i słowach to, czego „przykłady przodków” (maiorum exempla) są przykładami: cnotę - virtus, ową „sprawność umysłu dobrze ukształtowanego" - habitus mentis bene constitute, ową „właściwość prawie niewzruszalną” (II.24.93), która Diogenesowi z Synopy każe ze świecą szukać ludzkiego człowieka, a Diogenesowi z Babilonu pozwala znajdować go w sobie.

Odłoży pióro Wincenty, złamie je czy też przywiedzie do całkowitego zużycia? Czy zamiar napisania tekstu niemożliwego nie może nie skutkować tekstem poro-

18 „Ten właśnie wyjęty z kontekstu przykład wyniesiony został do roli ogólnej zasady filozoficznej w mowie Zbigniewa" — Z. Kałuża, D. Calma, O filozoficznych lekturach Mistrza Wincentego, [w:] Onus Athlanteum. Studia nad Kronika biskupa Wincentego, A. Dąbrówka, W. Wojtowicz (red.), Warszawa 2009, s. 242. Inny fragment z Topik (101b) został zawarty przez Kadłubka w pozytywnej opinii arcybiskupa Jana na temat rozprawy sądowej nad Zbigniewem, w której należnie wyczerpano kanon argumentacyjny tak, że nawet oskarżony „temat mowy miał dobrze obmyślony" — sufficiens dicetur habere propositum.

19 Św. Bernard z Clairvaux, De gradibus humilitatis et superbiae, I, 1 (PL 182, 941) [przekład polski: O stopniach pokory i pychy, tłum. S. Kiełtyka, Kraków 1991, s. 15]. 
nionym ${ }^{20}$, gdy cel pisania, jak horyzont, oddala się w miarę zbliżania się doń: Aplanon axe tero, scribens Cato paruus Homero — „nieboskłon wozem przemierzam, mały ja Katon piszac do Homera" (IV.17.229)?

\section{Studium humanitatis}

Będzie przeto cnota jako habitus i qualitas prawdziwym podmiotem kroniki Kadłubka - ograniczonej niby klamrą dwoma orędziami na temat umiejętności zarazem czynienia siebie jawnym i pozostawania w ukryciu, bez której trudno człowiekowi w obliczu innych ludzi pozostać człowiekiem. Jako affabilitas bliskoznaczna jest przyjaźni (amicitia), stając się jej synonimem w Arystotelesowi zawdzięczanym $^{21}$, a cyzelowanym przez św. Tomasza z Akwinu pytaniu, czy przyjaźń jawi się cnotą (virtus specialis), czy też raczej czymś z cnotą związanym (propter virtutem), oraz w jakiej mierze wolno ją uznać za część sprawiedliwości (pars iustitiae)22. Jako amicitia imperpefecta zaś otwiera affabilitas namysł nad etycznac powinnością życzliwego odnoszenia się do innych w warunkach nierówności i niedostatecznej wiedzy o sobie, które określają codzienność człowieka jako jestestwa towarzyskiego, społecznego i politycznego, a także zasadniczą treść podejmowanego w kronice historiae meritum.

Nie znajdziemy w epoce Kadłubka historii jako autonomicznej dziedziny wiedzy, ściśle oznaczonej co do formy i przedmiotu, zwłaszcza zaś historii w naszym rozumieniu słowa - nauki krytycznej o faktach zaistniałych w przeszłości. Nie mieści się wówczas ani w obrębie dystynkcji genologicznych, sytuowana w ślad za Kwintylianem gdzieś pomiędzy prozą i poezją jako rodzaj „poematu ujętego w formę niewiązaną" (carmen solutum) ${ }^{23}$, ani bezpośrednio w kanonie siedmiu sztuk wyzwolonych, utrzymując się w swojej tradycyjnej, a zarazem potocznej wieloznaczności: jako res gestae — dziedzina rzeczy już dokonanych, jako cognitio historica - ich poznanie, wreszcie jako narratio rerum gestarum - opowieść o nich. Jawi się historia opowiadaniem o tym, co zdziałane, lecz także dydaktycznym przekazem (traditio) i estetycznym wystawieniem (expositio), mierzącymi się z niejednoznacznością sytuacji komunikacyjnej na styku kultur oralnej (oratio) i skrypturalnej (dictamen), z niedoborem źródeł i nadmiarem opinii, jak również ze spornym charakterem czasu samego - miary tego, co podlega zmianie, zara-

${ }^{20}$ Poczucie klęski towarzyszy autorowi Kroniki polskiej nie tylko w związku z doświadczeniami politycznymi. ,[...] wysiłek alegorysty, mający na celu uspójnienie przekazu, jak i mitograficzna zawartość legend wskazują w swej istocie na takie ambicje literackie i światopoglądowe oraz na takie wymagania względem rzeczywistości, jakich nie spełnia ani kronika, ani opisywana w niej historia" — P. Kozioł, Alegoria, narracja, niespójność, [w:] Onus Athlanteum..., s. 465. Na temat epicedionu na śmierć umiłowanego władcy - Kazimierza Sprawiedliwego, poetycko-dramatycznego fragmentu przyjmujacego formę rozprawy sądowej, której stronami są Wesołość i Żal, pisze tłumaczka: „Sens w tych wincentyńskich strofach jest ukryty i zawoalowany, wieloznaczny, i już wiemy, że miał być próbą pogodzenia sprzeczności, które do pogodzenia się nie nadają, bo taka jest ich natura" - B. Kürbis, Wstęp, s. CXIII.

21 Arystoteles, Etyka Nikomachejska 1155a.

22 Św. Tomasz z Akwinu, Summa Theologiae, II.II., q. 114, 1-2.

${ }^{23}$ Kwintylian, Kształcenie mówcy, X, 1, 31. Por. J. Korpanty, Historiografia rzymska epoki archaicznej i cycerońskiej, Wrocław 1977, s. 5. 
zem więc przeciwieństwa i naśladownictwa wieczności według modelowych, także dla Mistrza Wincentego, rozstrzygnięć platońskiego Timajosa pieczołowicie uzgadnianych w komentarzach Teodoryka z Chartres, Bernarda Silvestris i Wilhelma z Conches z biblijnym opisem stworzenia świata.

Niejednorodność czasu i jego podziałów, jak też wielość naturalnych i umownych temporalnych kadencji każe Izydorowi z Sewilli, którego wpływ na dziejopisarstwo wieków średnich jako autora Etymologii jest nie do przecenienia, mówić o genus historiae triplex (diarium-ephemeris, kalendaria, annales) ${ }^{24}$. Chociaż judeochrześcijańska linearna koncepcja czasu zdominowała właściwą helleńskiej starożytności koncepcję cykliczną, umożliwiając za sprawą św. Augustyna historiozoficzną refleksję nad dziejami jako sensowną całością, czas historyczny pozostaje pod normatywnym wpływem kalendarza liturgicznego, historia powszechna zaś wciąż rozprasza się i rozpada misteryjnie na lokalne, fragmentaryczne historiae osnute wokół losów poszczególnych osób, dynastii, państw i narodów. Relacja wpisana jest w naturalne cykle powstawania i ginięcia, narodzin i śmierci, ubiegajacc się kosztem protokolarności opisu o wirtualne, w porządku ludzkiego życia zazwyczaj nieosiągalne całości czasu. A przecież, jak przypomina Wincenty, parafrazując Senekę, ,wszystko jest cudze oprócz dwóch rzeczy, to jest duszy i czasu, które natura przekazała nam na własność" (II.11.56) ${ }^{25}$.

W Kronice Kadłubka ów synkretyczny rys, potęgowany splotem wątków chrześcijańskich i pogańskich, udziela się samej narracji, nadając jej oryginalny egzystencjalny wymiar, kiedy to czcigodni starcy — arcybiskup Jan i biskup Mateusz, „obaj w poważnym wieku, obaj poważnie myślący” (I.1.7), w czasie pisania kroniki już nieżyjący, umierają w niej, przerywając tok snutej przez siebie opowieści przy biesiadnym stole. Nikt z rozmówców nie powie wszystkiego, nikt nie będzie mówił do końca — oto ekonomia zarządzania czasem wolnym $(\sigma \chi 0 \lambda \eta ́)$, w którym podejmując studium wieczności, nie możemy liczyć na absolutorium. Czyni to u kresu życia pierwszeństwo życia nad filozofią wyjątkowo czytelnym. Również $\mathrm{w}$ momencie zawiązania dialogu starannie, ze względu na ograniczenia natury ludzkiej, iż mianowicie „w człowieku nie ma nic doskonałego nad samą niedoskonałość" (III.1.117-118), pomijane są punkty kulminacyjne w porządkach zarówno czasu opowiadania, jak i czasu opowiadanego. Mówi Jan słowami Platona, biorac do siebie słowa egipskich kapłanów skierowane do Solona, a traktujące o ,zawsze młodych Grekach": Non enim hodierni sumus, nec ulla hesternitatis est in nobis cana scientia — „dzisiejsi jesteśmy i nie masz w nas sędziwej wiedzy wczorajszo-

${ }^{24}$ Izydor z Sewilli, Etymologiae, I, 44, 1-3 (PL 82, 123-124).

${ }^{25}$ L.A. Seneca, Epistolae morales ad Lucilium, I, 3 [przekład polski: Listy moralne do Lucyliusza, tłum. W. Kornatowski, Warszawa 1961, s. 4]. We fragmencie tym Seneka pisze jedynie o czasie: „Wszystko, Lucyliuszu, jest nie nasze, tylko czas stanowi naszą własność. Tę jedną tylko pierzchliwą i ulotną rzecz dała nam natura w posiadanie, z którego może wyzuć nas każdy, kto chce”. Znamienne dla autora średniowiecznego uzupełnienie Zenon Kałuża interpretuje jako „filozoficzno-religijny i niekoniecznie chrześcijański akcent kroniki Wincentego" - Z. Kałuża, D. Calma, O filozoficznych lekturach Mistrza Wincentego, s. 260. Por. M. Żarowski, Drżenie filozofa. Seneka w kronice Kadłubka, [w:] Rzecz piękna, mądra, dobra i wszystko, co takie..., J. Zieliński, S. Barć, A. Lorczyk (red.), Wrocław 2014, s. 254. 
ści" (I.1.7) ${ }^{26}$. Mateusz wobec zadania odtworzenia godnych upamiętnienia czynów przyszłości poczytuje siebie za ,niemowlaka”, wyznając: „nawet zgoła nie wiem, czy chwilę obecną poprzedziło choćby mgnienie czasu" (I.2.9). Niebłahą jest wówczas rzeczą - u obu granic języka: między pierwszym a ostatnim słowem, ciszą i zamilknięciem, młodością i starością, zachętą a przestrogą, pochwałą i naganą, smutkiem i wesołością, rozumieniem i wyrozumiałością, doskonałością cnoty, iż człowiek sposobny jest do miłowania jej dla niej samej, a doskonałością tożsamą z poznaniem niepodobieństwa osiągnięcia jej w podksiężycowym świecie — móc w trakcie „najserdeczniejszą miłością ożywionych uroczystości biesiadnych” (IV .17.229), przejawiając dyspozycje tyleż etyczne, co dianoetyczne: urbanitas - ogładę, industria - pomysłowość i circumspectio — oględność, „wydawać się wszystkim nad-

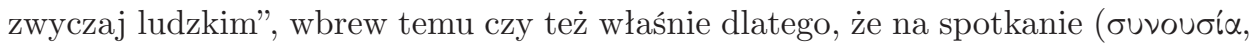
convivium) — zarówno wtedy, gdy wydarza się historia, jak i wtedy, gdy jest opowiadana, nigdy nie stawiają się wszyscy ${ }^{27}$.

Historia usiłująca wieczność (aeternitas) dopełnić perspektywami wieczystych i dożywotnich zobowiązań człowieka ,jest czymś doskonalszym od mniemania, jako że łączy się z mocnym przekonaniem, ale zarazem jest czymś mniej doskonałym od wiedzy, ponieważ nie opiera się na bezpośrednim oglądzie rzeczy samych"28. Metodologiczna samoświadomość dziejopisarzy, którzy uprzytamniają sobie coraz wyraźniej, że sami nie są, a nawet być nie powinni, naocznymi świadkami opisywanych przez siebie zdarzeń, a dystans czasowy i poznawczy jest zarazem ich przekleństwem i przywilejem, rośnie powoli, pozostawiając następcom większość hermeneutycznych odkryć, motywowaną tymczasem umiarkowanie przychylnymi opiniami Kwintyliana, Cycerona, Seneki, św. Augustyna, Izydora z Sewilli, Hugona od św. Wiktora, Jana z Salisbury co do wielorakich pożytków płynących dla duszy jednodniowej i nieśmiertelnej ze studiowania przeszłości. Pogląd Arystotelesowy, że historia jest mniej filozoficzna i poważna od poezji ${ }^{29}$, nakazuje autorom ostrożność

${ }^{26}$ Platon, Timajos 22b. Timaeus a Calcidio translatus, s. 14, 4-5. Pośród wspólnych motywów Kroniki Wincentego i platońskiego Timajosa wymienić można ,identyfikację niewiedzy z młodym wiekiem, nawet chłopięctwem, oraz wiedzy o przeszłości z wiekiem dojrzałym" - Z. Kałuża, Kadłubka historia mówiona..., s. 69. W samym przeciwstawieniu hodierni-hesterni słyszalna jest także Księga Hioba 8, 8-9. Zob. K. Chmielewska, Rola wątków i motywów antycznych w Kronice polskiej Mistrza Wincentego zwanego Kadłubkiem, Częstochowa 2003, s. 33.

${ }^{27}$ Komentarze Chalcydiusza do Timajosa Platona i Makrobiusza do Cycerońskiego Snu Scypiona oraz popularny wykład kosmologii Marcjana Capelli były w czasach Mistrza Wincentego bez mała jedynymi źródłami wiedzy na temat myśli platońskiej. Nasz kronikarz zaczerpnął z platońskiego Timajosa nie tylko kilka cytatów, lecz także ,strukturę, sposób narracji, a wreszcie sam pomysł opowiadania o przeszłości przy świątecznym stole" — Z. Kałuża, Kadłubka historia mówiona..., s. 87. Za właściwy początek tych ważkich zależności uznać można moment zawiązania dialogu między Mateuszem i Janem w Księdze I, gdzie „kadencja następstw jest frapująco podobna w obu dialogach” — ibidem, s. 70. Myślę jednak, że początek ten można cofnąć aż do paraleli między prologiem a dialogiem ramowym w Timajosie, gdzie trzej rozmówcy Sokratesa, próbując odwzajemnić gościnność filozofa okazaną im dnia poprzedniego, stają przed zadaniem podjęcia w rozmowie roli nieobecnego.

${ }^{28}$ K. Pomian, Przeszłość jako przedmiot wiary. Historia i filozofia w myśli średniowiecza, Warszawa 1968, s. 213.

29 „Historyk i poeta różnią się tym, że jeden mówi o wydarzeniach, które miały miejsce w rzeczywistości, a drugi o takich, które mogą się wydarzyć. Dlatego też poezja jest bardziej filozoficzna i poważna 
w szacowaniu własnych uprawnień i kompetencji — w jej ekspozycji trudno zaiste prolog Kroniki Kadłubka, a może i jej zakończenie, przelicytować.

W porządku szkolnym historia, na której ciąży odium zajmowania się tym, co syngularne: jednostkowe i pojedyncze, jednorazowe i niepowtarzalne, tym więc, o czym nie istnieje, ponieważ z natury rzeczy istnieć nie może, wiedza apodyktyczna, zaliczana jest do retoryki i gramatyki jako rozszerzenie zakresu ich formalnych konstatacji, łączona z polityką i etyką jako zasób pouczających przykładów, towarzyszy wreszcie w ramach teologii egzegezie Biblii jako jej sens literalny i zdarzeniowy, skoro Bóg, osiągając szczyty „pokory” i „ludzkości”, raczył ludziom jako człowiek objawić się w czasie ${ }^{30}$ i „uczyć się w czasie" (in tempore) tego miłosierdzia, którym sam był od wieków (ab aeterno $)^{31}$. Jan Szkot Eriugena porównuje tekst biblijny do świata złożonego z czterech elementów, gdzie ziemią znajdującą się „najniżej i pośrodku, na wzór centrum, jest historia” — otoczona wodą etyki, dalej „powietrzem wiedzy naturalnej”, wreszcie teologii „eterycznym i ognistym płomieniem"32. Ponieważ ,historią" jawi się najpierw ujmowany w formie czasowego następstwa sens narracji biblijnej, sztuki wyzwolone pozostają w służbie rozumienia historii sakralnej, historia świecka jest z kolei pokorną i pracowitą służką służek. Zajmuje, co znamienne, najniższe i zarazem centralne położenie, nie tylko czerpiąc swoją nieoficjalną powagę z ekwiwokacji tkwiącej w samym słowie „historia" wszak choć opowiada o „urządzeniach ludzkich” (hominum instituta), sama urządzeniem ludzkim nie jest ${ }^{33}$, lecz także pomiędzy obietnicą „dni ostatnich” i „pełni czasu" a dłużącym się oczekiwaniem na Paruzję uzupełniając chrześcijańskie doświadczenie czasowości i dziejowości, w którym, jak dowodzą tego Wyznania św. Augustyna, rośnie wartość najmniejszych nawet jednostek temporalnych.

Bezgraniczność pokory, z jaką Bóg stał się człowiekiem ${ }^{34}$, sprawia, że różnica między sermo sublimis a sermo humilis, zawarta i zatarta w samym Słowie ${ }^{35}$,

niż historia, poezja wyraża przecież to, co ogólne, historia natomiast to, co jednostkowe" — Arystoteles, Poetyka 1451b. Por. J. Domański, Dlaczego poezja jest bardziej filozoficzna od historii? Glosa do dziewiatego rozdziału Poetyki Arystotelesa, [w:] idem, Philosophica, paraphilosophica, metaphilosophica. Studia i szkice z dziejów myśli dawnej, Kraków 2008, s. 69-80.

30 Zob. J. Domański, Pomocnica nauki i teologii. Kilka watków metanaukowej refleksji nad historia w XII wieku, „Przegląd Tomistyczny” 9 (2003), s. 57-112; M. Zdanek, Obecność historii w nauczaniu $i$ refleksji krakowskiego środowiska uniwersyteckiego $w$ XV wieku, [w:] Przeszłość w kulturze średniowiecznej Polski, t. 1, J. Banaszkiewicz, A. Dąbrówka, P. Węcowski (red.), Warszawa 2018, s. 511-544.

31 Św. Bernard z Clairvaux, De gradibus humilitatis et superbiae, III, 10 (PL 182, 946-947) [przekład polski: O stopniach pokory i pychy, s. 27].

32 Jan Szkot Eriugena, Komentarz do Ewangelii Jana ( $Z$ Homilia do prologu Ewangelii Jana), tłum. A. Kijewska, Kęty 2000, s. 94. Agnieszka Kijewska pisze: „W wieku IX, czego doskonałym przykładem może być dzieło Eriugeny, Timajos wkracza w główny nurt myśli naukowej [...]" — eadem, Księga pisana i ksiega natury. Heksaemeron Eriugeny i Teodoryka z Chartres, Lublin 1999, s. 186.

33 Św. Augustyn, De Doctrina Christiana, II, 28, 44 (PL 34, 56).

34 „Bóg przyjął pokorny stan, kształt i wygląd, żebyśmy mogli poznać wspaniałość tej cnoty, dzięki wyjątkowemu zaszczytowi, jaki okazał jej zamieszkując w niej" - Św. Bernard z Clairvaux, De moribus et officio episcoporum, VI, 24 (PL 182, 825) [przekład polski: O obyczajach i obowiazku biskupów, tłum. S. Kiełtyka, Kraków 1992, s. 35].

35 Zob. E. Auerbach, Język literacki i jego odbiorcy w późnym antyku i łacińskim średniowieczu, tłum. R. Urbański, Kraków 2006, s. 29-64. 
torująca zaś drogę ku zarazem sformułowaniu i rozumieniu Boecjańskiej definicji osoby (persona est naturae rationabilis individua substantia), stawia przed warsztatem literackim dziejopisarstwa wymagania o najwyższym stopniu trudności. Nie dany jest historii prestiż wiedzy demonstratywnej w formie zarówno philosophia terrestris, jak i philosophia caelestis, jednocześnie zaś staje się bliska sentencjonalnej mądrości życiowej, imiennie dedykowanej człowiekowi — zwierzęciu z natury łagodnemu, doskonałemu w swej niedoskonałości, prawdziwie wolnemu w dawaniu z siebie wszystkiego, radosnemu w ubóstwie, zdolnemu na swoją miarę do odwzajemniania darów w warunkach nierówności. Mając przeto na myśli nie tylko ideały ascetycznego życia, lecz także deontologię własnej profesji, stwierdza Wincenty: „Tak dalece mądrość ukochała sobie kryjówkę niejako pod płaszczykiem prostaczka, gdy tymczasem przechwałka jest zawsze nieprzyjaciółką cnoty" (I.14.29). Res gestae - rzecz historii o powikłanym, niejednoznacznym statusie bytowym tkwi między tym, co ziszczone, a tym, co minione, aktualne i nieaktualne, tym, co należy nakłonić do powrotu, i tym, do czego samemu trzeba móc powrócić, nieprzypadkowo w ramach studium humanitatis, domagając się od historyka pokory — „cnoty, dzięki której człowiek, poznawszy się dokładnie, widzi swą marność”36.

Biblia w warstwie literalnej i historycznej objawia czasowe następstwo zdarzeń będące skądinąd znakiem ich ponadczasowości, tym bowiem różni się zdaniem św. Augustyna i Hugona od św. Wiktora od innych tekstów, a zbliża do otwartej księgi świata, że w niej znakami jawią się nie tylko słowa, ale i rzeczy. Stulecie XII, znajdujące się w ,stanie zawieszenia pomiędzy tym, co stare, a tym, co nowe"37, pogłębia pod wpływem lektury platońskiego Timajosa, w którym Demiurg stworzył człowieka, aby wyczerpać pojęcie ,żywego jestestwa”, tradycyjne związki gramatyki, retoryki i historii. Nacechowane symbolicznie universum Natury obejmuje bowiem byty, które będąc signa translata, kategoryzowane jako persona, tempus, gestus, locus, numerus, odpowiadają właśnie zainteresowaniom historyka, nawet jeśli odkrywane przez niego analogie są raczej retorycznymi figurami niż narzędziami metafizycznej eksplikacji pojęcia bytu. W tej mimetycznej przestrzeni staje człowiek, poszukując w byciu człowiekiem ludzkim szlachetnego sposobu stawania się tym, kim już jest, i równowagi pomiędzy łatwowiernością a niedowierzaniem, albowiem, dobrze to czy źle, ,szlachetny umysł nawet rzeczy niemożliwe sprowadza do stanu możliwości" (III.26.158) ${ }^{38}$.

Utrzymując wciąż więź z greckim źródłosłowem, „historia” oznacza świadectwo oparte na prostej zmysłowej obserwacji, a zarazem staje na jej antypodach jako coś, co było, a nie jest, do czego dostęp, nigdy naoczny, zapośredniczony jest w sferze opinii i mniemań innych. Rzeczy dokonane jako facta nie istnieją na tyle mocnym ontologicznie istnieniem, aby ewokować bezpośrednio wiedzę o sobie, i wbrew narzucającym się pozorom zawsze mogą się mieć inaczej, niż wydają się

${ }^{36}$ Św. Bernard z Clairvaux, De gradibus humilitatis et superbiae, I, 2 (PL 182, 942) [przekład polski: O stopniach pokory i pychy, s. 16].

37 A. Kijewska, Księga pisana..., s. 176.

38 Wypowiedź ta stanowi paralelę do Osio suo Calcidius, p. 5, 1-5, gdzie jednak mowa o cudownej sile samej cnoty. Zob. Z. Kałuża, D. Calma, The Philosophical Reading of Master Vincent, „Acta Poloniae Historica" 112 (2015), s. 54. 
mieć. Szczęśliwie byłość sąsiaduje z tym, co choć mogło się wydarzyć, nie zaistniało, a nawet z niebyłością tego, co w ogóle nie miało miejsca, ponieważ zaistnieć nie mogło, w ślad za czym Izydor z Sewilli dla wyjaśnienia tego, co wydarzyło się naprawdę, zaleca — oprócz prostego relacjonowania faktów odnoszącego się do natury pierwszej i ,argumentu” stanowiącego niejako naturą drugą — także „bajkę”, która contra naturam posługuje się fantazją i zmyśleniem ${ }^{39}$. Podobnie Jan z Salisbury wylicza refleksję, podobieństwo i przykład jako nieodzowne środki wzbogacenia prostego opisu zdarzeń, stwarzające w misternej pajęczynie dygresji i analogii okazję do duchowego ćwiczenia ${ }^{40}$. Każdą historię rozpocząć można od tego, co ją samą uniemożliwia lub unieważnia, tedy od słów: „Wprawdzie to, co sobie ułożyłem, wydaje się bajką, wszelako może pojmie kto sens zmyślonej przypowieści” (IV.26.267), zakończyć zaś w dowolnym miejscu wyznaniem: „Innym zdało się inaczej" (II.14.62).

Facta memorabilia to zdarzenia godne upamiętnienia, a jednocześnie możliwe do zapamiętania — opatrzone wspólną troską etyki i mnemoniki, sztuki narracyjnej i sztuki życia pojmowanej w duchu sokratejskiej i chrześcijańskiej ascezy jako ars moriendi. Faktyczność zdarzeń minionych wciąż czeka na swoją prawdę, czeka w o wiele trudniejszych niż metafizyczne warunkach, w rdzennej mianowicie dziedzinie ludzkich mniemań i opinii, gdzie w samym łonie najszczerszej przyjaźni „prawda rodzi nienawiść" — ueritas odium parit (IV.1.176) ${ }^{41}$ i miast jako transcendentalny analogon bytu i cel życia kontemplacyjnego stanowić u kresu poznania źródło szczęścia, wznieca pośród skrajnych namiętności niekończące się spory i kontrowersje. Ażeby kontrowersje te nie przestawały być konwersacjami marzącymi o konwersji i nie rozpadła się do reszty wspólnota komunikacyjna (universum, universitas), potrzeba amicitia que affabilitas dicitur - możności wytrwania w różnicy zdań na gruncie sztuki, z jaką jestestwo mowne i rozumne manifestuje wobec innych $\mathrm{w}$ gestach i słowach nie tylko wolę prawdomówności, lecz także iocunditas - niekłamaną „radość” ze spotkania.

Jak lojalnie przestrzega sam Kadłubek, „na rozmaity sposób snuje się pasmo opowieści" (II.14.61-62). Znamieniem i piętnem historii, jako opowieści jednej, a nawet jedynej z wielu, która tak czy inaczej popada w dotkliwą różnicę zdań, jest rozziew między faktami i aktami. To, co pozwala go przemagać w relacji historycznej, nazywane jest ,gestem" — już to działaniem niedokończonym, już to reakcją na część działania, jakby była jego całością, w każdym razie zewnętrznym, widomym, nieuchronnie więc teatralnym wyrazem czynu, który post factum należy jeszcze uwiarygodnić moralną intencją, kładąc kres anonimowości prawdy w nadziei właściwej humanistom, filologom i etykom, że „choćby [...] języki wszystkich milczały, własne zamysły człowieka o nim nie zamilczą" (II.28.102).

39 „Argumenty to te zdarzenia, które wprawdzie nie dokonały się, ale mogły się były dokonać” Izydor z Sewilli, Etymologiae, I, 44, 5 (PL, 82, 124); przekład za: K. Pomian, Przeszłość jako przedmiot wiary, s. 68.

40 B. Lapis, Jana z Salisbury rozumienie zadań historiografii, „Studia Źródłoznawcze” 15 (1971), S. $85-108$.

41 Słowa Terencjusza cytowane przez Cycerona w De amicitia $(24,89)$ i św. Augustyna w Wyznaniach (X, 23, 34) odnoszą się właśnie do przyjaźni. 
Kronikarz, piszący jakoby pod dyktando bezpośrednich świadków historii, czerpiący z ich świadectw ,nie tylko wiadomości o zdarzeniach, lecz również samą perspektywę widzenia owych zdarzeń" ${ }^{42}$, powinien poddać je surowej próbie etycznej akrybii, podobnie jak moralne kompetencje informatorów, zanim w formie virtutis exemplum powierzy je pamięci współczesnych i przyszłych czytelników. Deficyt prawdy faktycznej równoważony bywa opowieścią o tym, co sentencjonalnie ,,jest wielce prawdopodobne, a nawet więcej niż pewne (I.4.12), i co arcybiskupowi Janowi, niczym Sokratesowi słuchającemu Krytiasowej opowieści o Atlantydzie, pozwoli wykrzyknąć: Rem miram set fidei plenam! — „rzecz dziwna, lecz zupełnie wiarygodna" (I.10.23) ${ }^{43}$. Pomiędzy niedostatkiem i nadwyżką prawdy przychodzi najpierw historykowi kształcić w sobie na wskroś platońską, iście stoicką, dialektyczną, heurystyczną umiejętność zachowywania równowagi pomiędzy ostrożnością i pewnością, prawdą i prawdopodobieństwem, po to, ażeby nie tylko nie ustawać w drodze do prawdy, ale i nie przeoczyć momentu jej osiągnięcia - w obszarze twierdzeń, zważywszy na naturę ich przedmiotu, o pośrednim raczej stopniu ogólności, z jakim maja do czynienia ypóvnoıs i jej łacińska siostra Prudentia w konkluzjach uprawianej przez nie, a pozostającej w służbie ludzkiego działania sylogistyki.

Mimo nieobecności pośród dwunastowiecznych nauk i sztuk cieszących się szkolną licencją reprezentuje historiografia może najwierniej eklektyczną orientację epoki, w trakcie sumiennej „pracy encyklopedycznej”"44 próbując kolekcjami tropów i argumentów uzupełniać fundamentalny dla poznania przeszłości niedobór źródeł ${ }^{45}$. Przedmiotem i jednocześnie rezultatem tej pracy jest „,mentalność symboliczna”, polegajaca na „uregulowanej grze symbolizmu naturalnego, abstrakcyjnej alegoryki i typologii historycznej"46. Historia jako zdecydowanie bliższa literaturze niźli wiedzy demonstratywnej ${ }^{47}$, podobnie jak , ,iteratura najwierniej użycza w rozpaczy pocieszenia, w trudzie wytchnienia, w ubóstwie radości, umiarkowania w bogactwie i przyjemnościach" ${ }^{\prime 4}$. Jawi się w epoce Mistrza Wincentego zgodnie z wyrażeniem Hugona od św. Wiktora appendentia artium — wprawdzie nieco zbytkownym, lecz także użytecznym „uzupełnieniem sztuk”, będącym wypadkową raczej niż syntezą ,poznania bezpośredniego i wiary, przedmiotu i słowa, teraź-

${ }^{42}$ K. Pomian, Przeszłość jako przedmiot wiary, s. 63.

${ }^{43}$ Platon, Timajos 20d. Timeaus a Calcidio translatus, s. 12, 8.

${ }^{4}$ O. Balzer, Studyum o Kadłubku, t. 2, [w:] Pisma pośmiertne Oswalda Balzera, t. 2, Lwów 1935, s. 38. Przejawem owej encyklopedyczności są nieprzypadkowo w platońskim Timajosie znajdujące inspirację Planctus naturae Alana z Lille i De naturis rerum Aleksandra Neckama, a później Speculum Wincentego z Beauvais.

${ }^{45}$ M. Żarowski, Drżenie filozofa..., s. 240.

${ }^{46}$ P. Ricoeur, Struktura a hermeneutyka, tłum. K. Tarnowski, [w:] idem, Egzystencja i hermeneutyka. Rozprawy o metodzie, S. Cichowicz (wyb.), Warszawa 1985, s. 180.

47 „Renesans XII wieku zazwyczaj zrównywał poezję z filozofią” - E.R. Curtius, Literatura europejska i łacińskie średniowiecze, tłum. A. Borowski, Kraków 1997, s. 214.

48 In dolore solarium, recreatio in labore, in paupertate jucunditas, modestia in divitiis et deliciis, fidelissime a litteris mutuatur; Jan z Salisbury, Polycraticus I. prolog (PL 199, 586); B. Lapis, Jana z Salisbury rozumienie zadań historiografii, s. 107. 
niejszości i przeszłości, rozumu i autorytetu, widzenia i słyszenia" ${ }^{49}$. Rozeznając na potrzeby egzegezy biblijnej chronologiczne, topograficzne i prosopograficzne koordynaty, tkwi między tym, co jest znakiem prawdy żywej i objawionej, a tym, co jako literacki suplement do wiedzy nie może w pełni aspirować nawet do zwykłej prawdy materialnej. Marginalna, a jednocześnie wszechobecna, podrzędna i współśrodkowa pielęgnuje w sobie, podobnie jak dwunastowieczna filozofia, dążność do synergii fakultetów, która w momencie intelektualnego przesilenia odsłoni ukryte pokłady sapientia — boskiej i ludzkiej mądrości. Także tej, traktującej pod koniec historiograficznego dzieła o majestacie affabilitas - życzliwości, uprzejmości, ludzkości i o trudnej, by nie rzec: najtrudniejszej sztuce zachowywania złotego środka pomiędzy pobłażaniem sobie i innym w warunkach amicitia imperfecta.

\section{Pisanie historii jako uirtutis seminarium}

Poszukiwanie środka, a tym bardziej równowagi, nie może nie polegać, jak w tańcu, na ich miarowym traceniu i odzyskiwaniu, podobnie jak budowanie ,labiryntu Dedala" (III.17.136) i błądzenie w nim domaga się błędnika, a równocześnie jest już jego wyrabianiem i ćwiczeniem, także podczas lekcji kaligrafii ${ }^{50}$, która o ruchu jednostajnym wie odpowiednio dużo. Skazuje to nade wszystko dziejopisarza na chodzenie intertekstualnymi ,krętymi manowcami”, które sam tworzy, i na znajdowanie tego jedynie, z czym szuka. A przecież, jak czytamy, ,wiek XII był wiekiem poszukującym równowagi we wszystkim, równowagi między filozofią i teologią, między filozofią i poezją, między rozumem i wiarą, myślą i wyobraźnią, między nauką i kontemplacją, Arystotelesem i Platonem, przyrodą i człowiekiem"51. Kadłubkowy Mateusz, usprawiedliwiajacc swoje i Jana erudycyjne dygresje, pisze, iż ex industria — „rozmyślnie” rozwijaja je w rozmowie ,zarówno dlatego, że podobne rade podobnemu, jak i dlatego, że tożsamość jest matką społeczności (idemptitas mater est societatis), wreszcie, aby zgoła nie zabrakło przedmiotu, na którym czytelnik mógłby się ćwiczyć" (II.1.40). W innym zaś miejscu czytamy: ,skoro nie ma żadnej sposobności do ćwiczenia odwagi, to trzeba ją sobie wymyślić" (I.5.14). Już samo „unikanie bezczynności" ${ }^{\prime 2}$ jest „niemałym zasiewem dzielności (uirtutis seminarium)", a człowiek sumienny ,z zabaw czerpie niekiedy nie najmniejszą zaprawę do zajęć poważnych" (IV.5.189). Ludyczność i niepozorność historii koncentruje się na rzeczach, które choć w najlepszym razie ,niemałe” i „nie najmniejsze”, a zakrawające na „błahostki” - minima, rosną in humanis rebus właśnie wtedy, gdy się je pomija. Na nich też, przekonany, że ,ćwiczenie czyni mistrza” (III.8.124), domy-

${ }^{49}$ K. Pomian, Przeszłość jako przedmiot wiary, s. 97.

${ }^{50}$ Dzięki rozumowi, który wielość dźwięków ludzkiej mowy ujął w kształt liter, możliwe stały się ,i rozmowy z nieobecnymi, i trwałe oznajmienia naszej woli, i uwiecznianie zdarzeń przeszłych" — M.T. Cyceron, O państwie, III, 2, 3, [w:] idem, Pisma filozoficzne, t. 2, s. 113-114.

${ }^{51}$ M. Frankowska-Terlecka, Wstęp. Filozofia XII wieku, [w:] Wszystko to ze zdziwienia. Antologia tekstów filozoficznych z XII wieku, M. Frankowska-Terlecka (wyb.), Warszawa 2006, s. XIV.

52 Gall Anonim przyznaje, że pisze, aby „zachować wprawę w dyktowaniu” — Anonim tzw. Gall, Kronika polska, tłum. R. Grodecki, Wrocław-Warszawa-Kraków-Gdańsk-Łódź 1982, s. 115. 
ślając się reguł Boecjuszowej musica humana ${ }^{53}$, dziejopisarz kształci dystynktywność przemawiania, powiadania i myślenia, albowiem „, ludzkim rozeznaniu (in humana circumspectione) nie masz nic doskonałego" (III.1.117), nic prócz samego rozeznania, którego brak, zwłaszcza w perspektywie etycznego namysłu, gdzie za całą mądrość starczyć musi roztropność, nigdy przecież nie bywa zupełny.

To, co było, a nie jest, pozbawione bytowej i poznawczej dyscypliny poszukuje pomocy języka i zgodnie z zapewnieniami Kwintyliana, Cycerona czy św. Augustyna znajduje ją, jakkolwiek „wśród opowiadania [...] zawodzi rozum, zrozumieniu nie dopisuje mowa, a słowa nie wyjaśniają rzeczy zgodnie z tym, co zaszło" (II.20.7778). Już gramatyka, będąca historiae custodia — „opiekunką historii”, poprzez doskonalenie reguł językowej poprawności pozwala wyartykułować pierwsze kryteria wiarygodności świadectw i źródeł, wytyczając drogę dyskursowi pomnemu własnych ograniczeń, usiłującemu uprzedmiotowić rzeczy minione (praeterita) i sprawić, aby wbrew własnej naturze i zachłanności upływającego czasu rzeczami dopiero się stawały. Dzieło to podejmuje również retoryka, upatrujacc w stylu poważnym - stilus gravus, którego nie kto inny jak Diogenes z Babilonu wydaje się uosobieniem, najbardziej odpowiednią formę wyrazu nie dlatego nawet, że styl ten jest wzniosły i górnolotny, skłonny do słownej gry, peryfraz, szyku przestawnego i wybujałej metaforyki, lecz z uwagi na jego płynną potoczystość uzupełniającą brak czasowego continuum oraz na największą, aż po wrażliwą na sąsiedztwo brzmienia i znaczenia paronomazję, krytyczność. Będą przeto affabilitas, comitas, humanitas cnotami społecznymi związanymi z kulturą słowa, która pozwala przy biesiadnym stole delektować się przelotna jednością zdarzenia i znaczenia: „Przecież taką samą niepodzielną jaźń takiej samej duszy (animae indiuiduum) i natura nam dała, i nieustanna miłość ją zapala" (IV.26.272) ${ }^{54}$.

Wnikliwi i poważni poszukiwacze mądrości, którzy dają się jej poznać: Wilhelm z Conches, Jan Salisbury, Piotr Abelard, Bernard Silvestris rekomendują integumentum — „płaszcz poetycki” i involucrum — „otulinę słowną” jako nacechowany w równej mierze odpowiedniością słowa, co odpowiedzialnością za słowo sposób rozumienia i interpretacji innych wprawdzie znaczeń niż biblijne, przydających wszelako tekstom mniej natchnionym rangę komentarzy do apokryficznej księgi Natury, w której gwoli chronienia tajemnicy przed profanami relacje między tym, co wewnętrzne, i tym, co zewnętrzne, mikrokosmosem i makrokosmosem, Stwórcą i stworzeniem, traktowane są z należytą dyskrecją.

Alegoria - pisze Agnieszka Kijewska — jest to taka forma wypowiedzi, która ukrywa prawdziwe znaczenie, różne od znaczenia zewnętrznego, pod formą historycznego opowiadania. Integumentum zaś

${ }^{53}$ Musica humana sytuowana według De institutione musica Boecjusza, w ślad za Platonem, pomiędzy musica mundana i musica instrumentalis. Zob. T. Michałowska, Średniowiecze, Warszawa 1995, s. 35; A. Kijewska, Filozof i jego muzy. Antropologia Boecjusza - jej źródła i recepcja, Kęty 2001, s. 250.

${ }^{54}$ Wyrażenie animae indiuiduum przypisuje Kadłubek księciu Władysławowi Laskonogiemu temu samemu, któremu poświęca ostatnie akordy kroniki — w kontekście wyrażanych w liście do Leszka Białego nader subtelnych rozważań moralnych i prawnych na temat rywalizacji o tron krakowski. Dowiadujemy się przy okazji swoistej rozprawki o wierze, wierności i wdzięczności, że ,równowaga rozumu (status rationis) nie znosi, aby zdrowy umysł sprzeciwiał się i wadził z samym sobą”, a ,,jednakowość przekonań (idemptitas animorum) nie daje przystępu przeciwieństwu" (IV.26.272). 
jest wypowiedzią, która zamyka prawdziwy sens pod zmyśloną opowieścią. Tutaj — bajka, tam — historia kryją tajemnicze misterium ${ }^{55}$.

W rzeczy samej na określenie nadnaturalnych, cudownych, zdumiewajacych zdarzeń znajdujemy w Kronice polskiej obok miraculum słowa numen i mysterium, przez jednych badaczy kojarzone ze św. Bernardem jako ,wskazujące niedwuznacznie na mistyczną koncepcyę rzeczy" ${ }^{\prime 56}$, przez innych zaś łączone z hermetycznymi inklinacjami szkoły chartryjskiej ${ }^{57}$. Numen i mysterium są w świecie przedstawianym przez Kadłubka przejawami tajemnego, głębokiego, poufnego przymierza między Bogiem, stanowiącym wzorzec ludzkości i uczącym się miłosierdzia w czasie, a ludźmi o szlachetnych umysłach, w czasie sobie powierzonym miłującymi cnotę dla niej samej, a przez to „rzeczy niemożliwe” — res impossibiles sprowadzajacymi do stanu możliwości — ad possibilem facultatem. Dzięki tej nigdy nieprzedawnionej, zasługującej na miano religio więzi, która jest, nawiasem mówiąc, jedynym remedium na narastający pesymizm historyka, może Kadłubkowy św. Wojciech zachęcać Bolesława Chrobrego: „we wszystkim więc, synu, co czynisz, zapożyczaj wzór ze zwierciadła boskiej sprawiedliwości" (II.19.53). Może również książę Kazimierz Sprawiedliwy w chwilach pozornej beztroski przy biesiadnym stole, „niekiedy przygrywając na organach lub śpiewem wtórując chórowi, wczuwać się w słodycz niebiańskiej harmonii" (IV.6.194).

Wyrażając „artystyczną gościnność wobec czytelnika”58, ponawia Wincenty swój karkołomny lot Ikara lub błądzenie w labiryncie Dedala, przypominające namysł nad człowiekiem ludzkim, jego zwyczajnością i nadzwyczajnością, znikomością i wielkością, a nawet, z uwagi na ,subtelną grę analogii, podług tajemniczego stosunku między światem fizycznym i światem sakralnym"59, Naturą i Łaską, stara się uczcić „,W człowieku nadludzki majestat" - transhumana in homine maiestas (I.7.18). „Ludzkość” zdobi człowieka bywałego, w obyciu ujmującego, uprzejmego, życzliwego, skłonnego do muzykowania i biesiadowania, obdarzonego pogodą ducha (eutrapelia, iocunditas) i wyrozumiałością, ale także hojnością (liberalitas), który dostępując szczytów osobistej wolności, bierze wyłącznie po to, aby móc wciąż dawać - w tym znaczeniu nigdy nie brakuje mu niczego. Wiąże się ludzkość z cnotą oględności, wielkoduszności, wyrozumiałości i miłosierdzia, które jej, jako przez chwilę kardynalnej, są przydane: „Zmiłować się jednak należy, ponieważ żadna inna zaleta nie jest tak właściwa majestatowi władcy jak ludzkość (humanitas), gdyż jedynie przez nią naśladujemy Boga" (II. 28.113).

${ }^{55}$ A. Kijewska, Księga pisana i księga natury..., s. 188. ,»Filozoficzna« interpretacja Prologu zakłada zdolność odbiorcy do wydobycia tego, co, głęboko ukryte, stanowi istotę rzeczy. Integumentum staje się zatem techniką interpretacji” - W. Wojtowicz, Niektóre aspekty retoryczne..., s. 47. Zob. J. Dane, Integumentum as Interpretation: Note on Wiliam of Conches Commentary on Macrobius, „Classical Folia" 32 (1978), s. 206 n.

56 O. Balzer, Studyum o Kadtubku, t. 1, s. 403.

${ }^{57}$ Ibidem, s. 500; B. Kürbis, Wstęp, s. 133, przyp. 70.

58 A. Dąbrówka, W. Wojtowicz, Wstęp, [w:] Onus Athlanteum..., s. 23.

${ }^{59}$ M.D. Chenu, La théologie au XIIe siècle, Paris, 1957, s. 160; cyt. za: P. Ricoeur, Struktura a hermeneutyka, s. 178 . 
Oparte na nierówności i niedostatecznym rozpoznaniu związki przyjacielskie, doraźne w perspektywie wieczności, których kruchą niezawodność podtrzymują $\mathrm{w}$ sobie affabilitas i humanitas, bliskie są nie tylko codziennemu, międzyludzkiemu bytowaniu, ale i cnotom wierności oraz sprawiedliwości, gdy odwzajemnienie darów graniczy z niepodobieństwem. Dzięki ludzkości właśnie postać księcia Kazimierza wyłania się z wyblakłych stronic, zyskując mistyczny, co więcej: zmysłowy charakter — władcy umiłowanego, którego śmierć i na tę śmierć napisany przez Kadłubka epicedion, rozdzierane pogłoską o truciźnie, najbardziej może stosowne były po temu, aby zamknąć lub urwać Kronikę polska wieńczącym, dramatycznym gestem. Ludzki, cnotliwy człowiek u władzy, największej — bycia sobą, ów pomazaniec ludzkiego Boga porównany zostaje do biblijnego drzewa oliwnego ${ }^{60}$, którego „zapach wszystkim dobrze jest znany, a jednak nikomu nieznany; wszystkim jest swojski, wszystkim obcy" (IV.5.187).

\section{Bibliografia}

Anonim tzw. Gall, Kronika polska, tłum. R. Grodecki, Wrocław-Warszawa-Kraków-Gdańsk-Łódź 1982.

Auerbach E., Język literacki i jego odbiorcy w późnym antyku i łacińskim średniowieczu, tłum. R. Urbański, Kraków 2006.

Balzer O., Studyum o Kadłubku, t. 1-2, [w:] Pisma pośmiertne Oswalda Balzera, Lwów 1934-1935.

Borawska D., Mistrz Wincenty w nowym wydaniu i opracowaniu. W stronę cystersów $i$ św. Bernarda z Clairvaux, „Przegląd Historyczny” 68 [2] (1977), s. 341-366.

Chmielewska K., Rola wątków i motywów antycznych w Kronice polskiej Mistrza Wincentego zwanego Kadłubkiem, Częstochowa 2003.

Curtius E.R., Literatura europejska i łacinskie średniowiecze, tłum. A. Borowski, Kraków 1997.

Cyceron M.T., O państwie, [w:] idem, Pisma filozoficzne, tłum. W. Kornatowski, t. 2, Warszawa 1960.

Cyceron M.T., O powinnościach, [w:] idem, Pisma filozoficzne, tłum. W. Kornatowski, t. 2, Warszawa 1960.

Dane J., Integumentum as Interpretation: Note on Wiliam of Conches Commentary on Macrobius, „Classical Folia” 32 (1978), s. 201-215.

Domański J., Dlaczego poezja jest bardziej filozoficzna od historii? Glosa do dziewiatego rozdziału Poetyki Arystotelesa, [w:] idem, Philosophica, paraphilosophica, metaphilosophica. Studia i szkice z dziejów myśli dawnej, Kraków 2008, s. 69-80.

${ }^{60}$ Księga Sędziów 9, 8-11. Porównanie człowieka cnotliwego do drzewa oliwnego mógł Wincenty powziąć za pośrednictwem św. Bernarda i przenikniętej duchem mistycyzmu literatury cysterskiej — D. Borawska, Mistrz Wincenty w nowym wydaniu $i$ opracowaniu. W stronę cystersów $i$ św. Bernarda z Clairvaux, „Przegląd Historyczny” 68 [2] (1977), s. 359-360. Osoba władcy reprezentuje Boga-człowieka w wymiarze politycznym, tyleż ujawniając, co skrywając sakralny, liturgiczny i charyzmatyczny sens władzy królewskiej — E. Kantorowicz, Dwa ciała króla. Studium ze średniowiecznej teologii politycznej, tłum. M. Michalski, A. Krawiec, Warszawa 2007, s. 22-25. 
Domański J., Pomocnica nauki i teologii. Kilka wątków metanaukowej refleksji nad historia w XII wieku, „Przegląd Tomistyczny” 9 (2003), s. 57-112.

Domański J., Prolog „Kroniki polskiej” Mistrza Wincentego zwanego Kadłubkiem. Próba enarracji, „Przegląd Tomistyczny” 12 (2006), s. 9-60.

Domański J., Sprawiedliwość i miłosierdzie w systemie cnót politycznych Wincentego Kadłubka, „Teologia Polityczna. Rocznik Filozoficzny” 1-2 (2003-2004), s. 154-163.

Frankowska-Terlecka M., Wstęp. Filozofia XII wieku, [w:] Wszystko to ze zdziwienia. Antologia tekstów filozoficznych z XII wieku, M. Frankowska-Terlecka (wyb.), Warszawa 2006, s. XI-XXVII.

Jan Szkot Eriugena, Komentarz do Ewangelii Jana (Z Homilia do prologu Ewangelii Jana), tłum. A. Kijewska, Kęty 2000.

Kałuża Z., Kadtubka historia mówiona i historia pisana („Kronika” I 1-2, I 9 i II 1-2), „Przegląd Tomistyczny” 12 (2006), s. 61-120.

Kałuża Z., Calma D., O filozoficznych lekturach Mistrza Wincentego, [w:] Onus Athlanteum. Studia nad Kronika biskupa Wincentego, A. Dąbrówka, W. Wojtowicz (red.), Warszawa 2009, s. 231-278.

Kałuża Z., Calma D., The Philosophical Reading of Master Vincent, „Acta Poloniae Historica" 112 (2015), s. 47-107.

Kantorowicz E., Dwa ciała króla. Studium ze średniowiecznej teologii politycznej, tłum. M. Michalski, A. Krawiec, Warszawa 2007.

Kijewska A., Filozof i jego muzy. Antropologia Boecjusza - jej źródła i recepcja, Kęty 2001.

Kijewska A., Ksiega pisana i ksiega natury. Heksaemeron Eriugeny i Teodoryka z Chartres, Lublin 1999.

Korpanty J., Historiografia rzymska epoki archaicznej i cyceronskiej, Wrocław 1977.

Kozioł P., Alegoria, narracja, niespójność, [w:] Onus Athlanteum. Studia nad Kronika biskupa Wincentego, A. Dąbrówka, W. Wojtowicz (red.), Warszawa 2009, s. 459465.

Kraszewski J.I., Odczyty o cywilizacyi w Polsce, Warszawa 1861.

Kürbis B., Wstę, [w:] Mistrz Wincenty (tzw. Kadłubek), Kronika Polska, s. IIICXXXI.

Lapis B., Jana z Salisbury rozumienie zadań historiografii, „Studia Źródłoznawcze” 15 (1971), s. 85-108.

Mańkowski J., Krak, uczeń Sokratesa (glosa do Kadtubka Chronica Polonorum I 5,3), [w:] Inspiracje platońskie literatury staropolskiej, A. Nowicka-Jeżowa, P. Stępień (red.), Warszawa 2000, s. 147-150.

Michałowska T., Średniowiecze, Warszawa 1995.

Mistrz Wincenty (tzw. Kadłubek), Kronika Polska, tłum. B. Kürbis, Wrocław-Warszawa-Kraków 1992.

Plezia M. (red.), Magistri Vincentii dicta Kadłubek Chronica Polonorum, Kraków 1994.

Pomian K., Przeszłość jako przedmiot wiary. Historia i filozofia w myśli średniowiecza, Warszawa 1968.

Ricoeur P., Struktura a hermeneutyka, tłum. K. Tarnowski, [w:] idem, Egzystencja $i$ hermeneutyka. Rozprawy o metodzie, S. Cichowicz (wyb.), Warszawa 1985, s. 147181. 
Seneka, L.A., Listy moralne do Lucyliusza, tłum. W. Kornatowski, Warszawa 1961.

Skibiński E., Gramatyka i retoryka w „Chronika Polonorum” mistrza Wincentego zwanego Kadtubkiem. Forma językowa na usługach myśli [praca doktorska napisana pod kierunkiem B. Kürbis, Poznań 1993].

Św. Bernard z Clairvaux, O obyczajach i obowiazku biskupów, tłum. S. Kiełtyka, Kraków 1992.

Św. Bernard z Clairvaux, O stopniach pokory i pychy, tłum. S. Kiełtyka, Kraków 1991.

Tatarkiewicz W., Dzieje sześciu pojęć, Warszawa 1982.

Waszink J.H. (red.), Timaeus a Calcidio translatus commentarioque instructus, London-Leiden 1975.

Wojtowicz W., Niektóre aspekty retoryczne Prologu Kroniki Mistrza Wincentego, [w:] Teatr wymowy. Formy i przemiany retoryki użytkowej, J. Sztachelska, J. Maciejewski, E. Dąbrowska (red.), Białystok 2004, s. 41-51.

Zdanek M., Obecność historii w nauczaniu i refleksji krakowskiego środowiska uniwersyteckiego w XV wieku, [w:] Przeszłość w kulturze średniowiecznej Polski, t. 1, J. Banaszkiewicz, A. Dąbrówka, P. Węcowski (red.), Warszawa 2018, s. 511-544.

Żarowski M., Drżenie filozofa. Seneka w kronice Kadłubka, [w:] Rzecz piękna, madra, dobra i wszystko, co takie..., J. Zieliński, S. Barć, A. Lorczyk (red.), Wrocław 2014, s. $237-262$. 